\title{
Color Doppler imaging of the ophthalmic artery in patients with chronic heart failure
}

\section{Ultrassonografia Doppler em cores da artéria oftálmica em pacientes com insuficiência cardíaca crônica}

\author{
Daniela B. Almeida-Freitas ${ }^{1}$, Daniel Meira-Freitas ${ }^{2}$, Luiz Alberto Soares de Melo JR. ${ }^{2}$, Augusto Paranhos Jr. ${ }^{2}$, Wagner Iared $^{1}$, Sergio Ajzen ${ }^{1}$
}

\begin{abstract}
Purpose: To evaluate the ophthalmic artery hemodynamics in patients with chronic heart failure.

Methods: Doppler parameters of ophthalmic artery of 18 patients with chronic heart failure in different stages of the disease were compared with 21 healthy volunteers (control group). These parameters were also correlated with echocardiographic assessments and clinical cardiologic status.

Results: Mean diastolic velocity was $5.14 \pm 2.4 \mathrm{~cm} / \mathrm{s}$ in the chronic heart failure group and $7.44 \pm 3.5 \mathrm{~cm} / \mathrm{s}$ in the control group ( $p=0.007$ ). Mean resistance index of the ophthalmic artery was $0.76 \pm 0.08$ in the chronic heart failure group and $0.70 \pm 0.08$ in the control group $(p=0.04)$. Mean systolic velocity of the ophthalmic artery was $22.03 \pm 7.7 \mathrm{~cm} / \mathrm{s}$ in the chronic heart failure group and $25.32 \pm 9.2 \mathrm{~cm} / \mathrm{s}$ in the control group $(p=0.24)$. There was a negative correlation between the resistance index of the ophthalmic artery and systemic blood pressure of patients with chronic heart failure $(r=-0.47, p=0.007)$. Diastolic velocity of the ophthalmic artery correlated positively with systemic blood pressure $(r=0.44, p=0.02)$

Conclusion: Lower diastolic velocity and higher resistance index were observed in the ophthalmic artery of chronic heart failure patients when compared to the control group, which probably reflects the presence of orbital vasoconstriction in response to low cardiac output. Therefore, the influence of these findings on the structure and function of the optic nerve head deserves investigation.
\end{abstract}

Keywords: Echocardiography, Doppler, color; Blood flow velocity; Heart failure; Chronic disease; Intraocular pressure; Ophthalmic artery

\section{RESUMO}

Objetivo: Avaliar o fluxo sanguíneo da artéria oftálmica em pacientes com insuficiência cardíaca crônica.

Métodos: Parâmetros da ultrassonografia Doppler em cores da artéria oftálmica de 18 pacientes com insuficiência cardíaca crônica em diferentes estágios da doença foram comparados com 21 voluntários saudáveis (grupo controle). Estes parâmetros foram também correlacionados com avaliação ecocardiográfica e quadro clínico cardiológico. Resultados: A média da velocidade diastólica foi $5,14 \pm 2,4 \mathrm{~cm} / \mathrm{s}$ no grupo insuficiência cardíaca crônica e $7,44 \pm 3,5 \mathrm{~cm} / \mathrm{s}$ no grupo controle $(p=0,007)$. O índice de resistência da artéria oftálmica foi de 0,76 $\pm 0,08$ no grupo insuficiência cardíaca crônica e 0,70 \pm 0,08 no grupo controle $(p=0,04)$. A média de velocidade sistólica da artéria oftálmica fol $22,03 \pm 7,7 \mathrm{~cm} / \mathrm{s}$ no grupo insuficiência cardíaca crônica e 25,32 $\pm 9,2 \mathrm{~cm} / \mathrm{s}$ no grupo controle $(p=0,24)$. A pressäo arterial sistêmica dos pacientes com insuficiência cardíaca crônica correlacionou-senegativamente com o índice de resistência da artéria oftálmica $(r=-0,47, p=0,007)$ e positivamente com a velocidade diastólica da artéria oftálmica $(r=0,44, p=0,02)$

Conclusão: Velocidade diastólica mais baixa e índice de resistência mais alto foram observados na artéria oftálmica de pacientes com insuficiência cardíaca crônica quando comparados ao grupo controle, o que provavelmente reflete a presença de vasoconstrição orbitalem resposta ao baixo débito cardíaco. Portanto, a influência desses achados sobre a estrutura e função da cabeça do nervo óptico merece ser investigada.

Descritores: Ecocardiografia Doppler em cores; Velocidade do fluxo sanguíneo; Insuficiência cardiaca; Doença crônica; Pressão intraocular; Artéria oftálmica

\section{INTRODUCTION}

Ocular blood flow may be affected in some ocular diseases, including glaucoma. Glaucoma is a progressive optic neuropathy that presents as a distinct appearance of the optic disc and visual field loss, being the leading cause of irreversible blindness worldwide ${ }^{(1-4)}$. The vascular theory describing the mechanism of glaucoma considers the optic neuropathy as a consequence of insufficient blood perfusion due to either increased intraocular pressure or other risk factors which may lead to a reduction in the ocular blood flow ${ }^{(2)}$. Several studies have demonstrated that the reduction of the optic nerve head perfusion is associated with glaucoma ${ }^{(2,5-8)}$. The Barbados Eye Study found a higher incidence of glaucoma in patients with lower systolic blood pressure and lower ocular perfusion pressure ${ }^{(9)}$. Several studies have shown that patients with large fluctuations in blood pressure at night present a higher risk for glaucoma progression ${ }^{(10-12)}$. In the Ocular Hypertension Treatment Study, previous history of heart disease was a risk factor for the development of glaucoma ${ }^{(13)}$. Additional evidence suggesting the importance of blood flow on the pathogenesis of glaucoma comes from reports of glaucomatous-like optic nerve and visual field damage secondary to transient hemodynamic shock ${ }^{(14)}$.

Chronic heart failure (CHF) is a serious and common condition, in which an abnormality of cardiac function is responsible for a failure of the heart to pump blood at a rate commensurate with the requirements of the metabolizing tissues ${ }^{(15)}$. A complex neurohormonal system is involved in an attempt to compensate heart failure, aiming to guarantee a suitable perfusion of the tissues ${ }^{(16)}$. However, studies indicate that the cerebral blood flow may be reduced in these patients ${ }^{(17-23)}$. The blood flow of the ophthalmic artery during heart failure and its possible role in the pathogenesis of glaucoma has not yet been investigated. The color Doppler imaging is a noninvasive, fast and easy access ultrasound technique, used in ophthalmology practice to measure the blood flow velocity of the orbital vessels $s^{(1-3,17-25)}$. The purpose of this study was to evaluate the blood flow of the ophthalmic artery in patients with chronic heart failure using color Doppler imaging. 


\section{METHODS}

A cross-sectional study was carried out. Patients with heart failure symptoms and left ventricle ejection fraction bellow 55\% documented by echocardiography were recruited from the outpatient cardiomyopathy and heart failure clinic of a tertiary care university hospital. Non-cardiopathic volunteers were included as a control group. The study was approved by the Institutional Review Board and followed the tenets of the Declaration of Helsinki. Informed consent was obtained from all subjects prior to the study and after an explanation of the nature and possible consequences of the study.

Heart failure cases or control subjects under 18 years of age, patients with prior history of significant ocular disease, ocular trauma or ocular surgery, chronic corticosteroid usage (topical or systemic), secondary glaucoma, dense media opacities, retinal disease, heart transplantation, stroke or any other neurological diseases were not included in the study.

The blood pressure readings for systolic and diastolic blood pressure were obtained after the participant was seated for 10 minutes. The mean arterial blood pressure was calculated according to the formula: mean arterial blood pressure $=2 / 3^{*}$ diastolic blood pressure $+1 / 3^{*}$ systolic blood pressure. The mean ocular perfusion pressure was calculated as: mean ocular perfusion pressure $=2 / 3^{*}$ mean arterial blood pressure - intraocular pressure ${ }^{(5)}$.

\section{Color Doppler imaging and ophthalmologic evaluation}

The ophthalmic artery blood flow velocity was measured by transpalpebral Doppler ultrasound (EnVisor - Philips Medical Systems, Bothell, WA, USA), with a linear high frequency transducer (10 MHz). The evaluated parameters were: systolic velocity, diastolic velocity and resistance index. Two radiologists examined both eyes of all subjects.

Patients were examined in the supine position, with their heads inclined at a $30^{\circ}$ angle. The transducer was covered in gel and gently placed externally upon the eyelid, avoiding excessive pressure. The flow velocity was measured at the medial proximal point of the ophthalmic artery using a wall filter of $100 \mathrm{~Hz}$ and sample of $0.12 \mathrm{~mm}$. Doppler insonation angle was adjusted between 0 and $40^{\circ}$. If the ophthalmic artery was not detected within 5 minutes, the examination was aborted in order to minimize ocular exposure to the ultrasound.

Once the waveforms of the ophthalmic artery were obtained, the values of systolic velocity, diastolic velocity and resistance index were calculated using the automatic algorithm of the machine (Figure 1). Three measurements were taken from all patients by each radiologist, and the mean value was considered for the analysis.

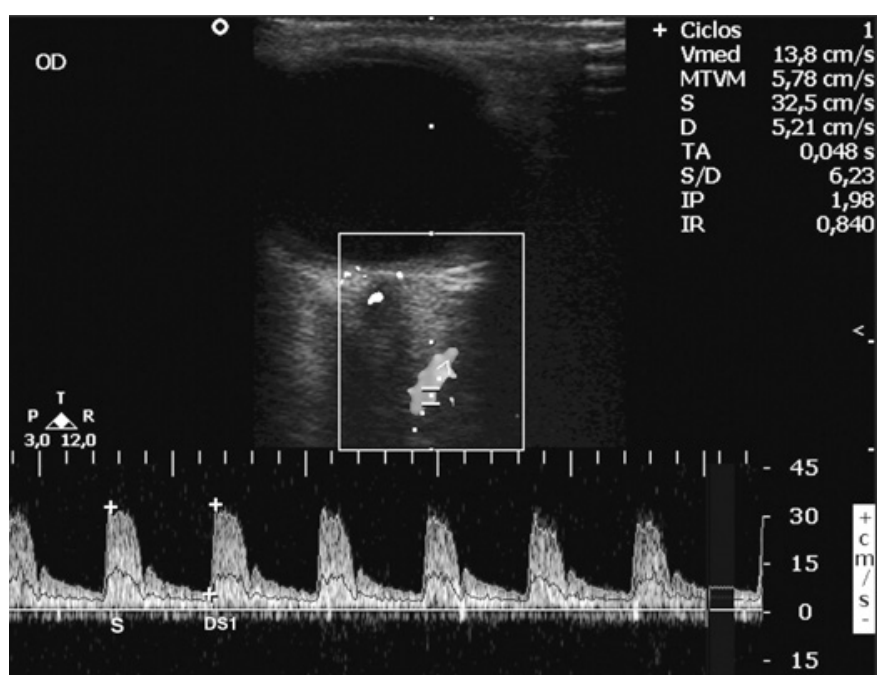

Figure 1. Velocity waveform (bottom) of the ophthalmic artery from a patient with chronic heart failure.
All subjects underwent a comprehensive ophthalmological examination including best-corrected visual acuity, slit-lamp examination, Goldmann applanation tonometry and fundoscopy. Tonometry was performed within 30 minutes after the arterial blood pressure measurement. All examinations were performed between 9 a.m. and $11 \mathrm{a} . \mathrm{m}$.

\section{Statistical analysis}

The correlations between the color Doppler ultrasound indices and left ventricle ejection fraction, functional classification (New York Heart Association - NYHA) and the measurements of blood pressure were calculated using the Spearman correlation test. To take into account the correlation between both eyes of the same individual, generalized estimating equation was used to compare the mean values between the groups. It was calculated that at least 36 eyes in each group were needed to have 90\% power to detect a 0.1 difference in the resistance index between the groups, considering a standard deviation of 0.1, an intracluster correlation between both eyes of the same individual of 0.58 , a design effect of 1.58 and a significance level of 0.05 . Results are expressed as mean \pm standard deviation (SD), and $P<0.05$ was considered statistically significant.

\section{RESULTS}

Eighteen CHF patients and 21 control participants (non-cardiopathic volunteers) were included in the study. No age or gender differences were observed between the CHF patents and the controls (Table 1). The results of systolic velocity, diastolic velocity and resistance index of the ophthalmic artery are summarized in table 2. Mean diastolic velocity was lower $(p=0.007)$ while mean resistance index was higher $(p=0.04)$ in the CHF patients when compared to the control group. Mean systolic velocity was not statistically significant different between the two groups ( $p=0.24)$. Mean systemic arterial blood pressure was significantly lower in the CHF group $(80.9 \pm 11.0 \mathrm{mmHg})$ than in the control group

Table 1. Baseline characteristics of the chronic heart failure and control groups

\begin{tabular}{lcc}
\hline & $\begin{array}{c}\text { Chronic heart failure group } \\
\text { (N=18) }\end{array}$ & $\begin{array}{c}\text { Control group } \\
\text { (N=21) }\end{array}$ \\
\hline Age (years), mean \pm SD & $50.2 \pm 11$ & $50.4 \pm 12$ \\
Male & $67 \%$ & $62 \%$ \\
Race & $5(28)$ & $8(39)$ \\
White, N (\%) & $3(17)$ & $4(17)$ \\
Black, N (\%) & $9(50)$ & $9(44)$ \\
Mixed, N (\%) & $1(5)$ & \\
Asian, N (\%) & & \\
Heart failure etiology & $39 \%$ & \\
Chagas & $22 \%$ & \\
Ischemic & $17 \%$ & \\
Idiopatic & $22 \%$ & \\
Others & $34 \%(14 \%$ to $45 \%)$ & \\
Ejection fraction of LV & & \\
Functional class of the & & \\
heart failure (NYHA) & & \\
I & $45 \%$ & \\
II & $33 \%$ & \\
III & $22 \%$ & \\
Medications & & \\
Diuretics & & \\
$\beta$-Blockers & $100 \%$ & \\
ACE inhibitors & $94 \%$ & \\
Digoxin & $94 \%$ & \\
\hline
\end{tabular}

$\mathrm{ACE}=$ angiotensin-converting enzyme; $\mathrm{NYHA}=$ New York Heart Association; $\mathrm{LV}=$ left ventricle; $\mathrm{SD}=$ standard deviation; $\mathrm{NA}=$ not applicable 
(104.0 $\pm 10.3 \mathrm{mmHg}$ ). Ocular perfusion pressure was significantly lower in the CHF group $(42.3 \pm 6.9 \mathrm{mmHg})$ than in the control group (54.1 $\pm 7.8 \mathrm{mmHg}$ ).

Resistance index of the ophthalmic artery had a statistically significant negative correlation with the systemic systolic $(r=-0.47$; $p=0.007)$ and diastolic arterial blood pressure $(r=-0.56 ; p=0.001)$. Diastolic velocity of the ophthalmic artery had a positive correlation with the systolic $(r=0.37 ; p=0.04)$ and diastolic arterial blood pressure $(r=0.44 ; 0=0.02)$. There were no statistically significant correlations between the Doppler parameters and the cardiologic evaluation (ejection fraction and functional class) of the heart failure patients (Table 3 ).

\section{DISCUSSION}

This study evaluated the ophthalmic artery blood flow in patients with heart failure. No similar study was found in the literature regarding this form of evaluation. Low cardiac output is associated with compensatory mechanisms of peripheral vasoconstriction in attempt to maintain satisfactory blood pressure and minimum perfusion to critical tissues such as the heart and brain ${ }^{(17,26)}$. On the other hand, the excessive vasospasm/vasoconstriction of the ocular vessels may be related to a reduction in the perfusion and tissue death at the optic nerve head ${ }^{(6)}$. Therefore, patients with CHF could present hemodynamic alterations of the ocular microvasculature and a higher risk of developing glaucoma. The color Doppler imaging of the ophthalmic artery with the velocity waveform in function of the heart cycle offers important information regarding hemodynamic pathophysiology.

The finding that low diastolic blood pressure correlates with high resistance index and low diastolic velocity of the ophthalmic artery possibly reflects the pathophysiology of heart failure and the presence of orbital vasoconstriction in response to low cardiac output. No correlation was found between left ventricle ejection fraction and the Doppler parameters, which is not surprising, since studies examining cerebral circulation had already shown that left ventricle ejection fraction is not directly related to the measured blood flow to this tissue ${ }^{(18)}$. In contrast with this result, some reports have suggested that a cardiac output increase is of higher relevance than the increase in blood pressure to maintain the cerebral blood flow $(19,23,27)$.
Regarding the heart failure functional classification, some studies have shown that the worsening of the functional class is related to low cerebral perfusion in patients with heart failure ${ }^{(18,19)}$ We observed no correlation between the heart failure functional classification (NYHA) and Doppler parameters of the ophthalmic artery. However, our experimental group is composed of outpatients (mostly functional classes I and II), unlike other studies involving patients with more uncontrolled disease (functional classes III and IV). Moreover, the findings of nuclear medicine and other techniques used in other studies, which assess flow rather than velocity, may not be comparable to the Doppler technique.

CHF patients had lower diastolic velocity and a higher resistance index in the ophthalmic artery when compared with the control group. Studies using color Doppler imaging found reduced systolic and diastolic velocity peaks, as well as, an increased resistance index in the retrobulbar vessels of patients with glaucoma in comparison with healthy subjects ${ }^{(2,3,5,8,24)}$. Velocimetric changes of the ophthalmic artery may be related to and even antedate the glaucomatous damage $(2,3,5,8,24)$. Therefore, it is possible that patients with CHF have a higher risk of developing normal tension glaucoma and the blood flow alterations may be related to its pathogenesis.

This study, however, presents a few limitations, such as the presence of heart disease at different stages and thus presents distinct risks of changes in the ocular microvasculature, which may have attenuated differences found between the groups. Moreover, despite the similarity of gender and age between the studied groups, other potential confounding factors were not controlled, such as carotid atherosclerosis and medication use. In addition, the color Doppler imaging simply measures velocities and not directly the blood flow.

\section{CONCLUSION}

This study demonstrated reduced diastolic velocity and increased resistance index in the ophthalmic artery of patients with heart failure. However, there was no correlation between the Doppler parameters of the ophthalmic artery, left ventricle ejection fraction and functional class. Systemic blood pressure may be a good clinical parameter in the determination of cardiac patients with a higher risk of developing ophthalmic vascular alterations. The results of this study suggest that heart failure could be a risk factor for low

Table 2. Hemodynamic parameters in chronic heart failure and control groups

\begin{tabular}{|c|c|c|c|}
\hline & CHF group $(\mathrm{N}=18)$ & Control group $(\mathrm{N}=\mathbf{2 1})$ & $\mathbf{P}$ \\
\hline Systemic systolic blood pressure $(\mathrm{mmHg})$, mean $\pm \mathrm{SD}$ & $100.8 \pm 12.3$ & $127.14 \pm 13.4$ & $<0.001$ \\
\hline Systemic diastolic blood pressure $(\mathrm{mmHg})$, mean \pm SD & $71.0 \pm 11.2$ & $92.50 \pm 9.6$ & $<0.001$ \\
\hline Mean arterial pressure $(\mathrm{mmHg})$, mean $\pm \mathrm{SD}$ & $80.9 \pm 11.0$ & $104.00 \pm 10.3$ & $<0.001$ \\
\hline Ocular perfusion pressure $(\mathrm{mmHg})$, mean $\pm \mathrm{SD}$ & $42.3 \pm 6.9$ & $54.10 \pm 7.8$ & $<0.001$ \\
\hline \multicolumn{4}{|l|}{ Color Doppler of the ophthalmic artery, mean \pm SD } \\
\hline Systolic velocity $(\mathrm{cm} / \mathrm{s})$ & $22.03 \pm 7.70$ & $25.32 \pm 9.20$ & 0.240 \\
\hline Diastolic velocity $(\mathrm{cm} / \mathrm{s})$ & $5.14 \pm 2.40$ & $7.44 \pm 3.50$ & 0.007 \\
\hline Resistance index & $0.76 \pm 0.08$ & $0.70 \pm 0.08$ & 0.040 \\
\hline
\end{tabular}

Table 3. Correlation between cardiologic evaluation and parameters of the Doppler of ophthalmic artery

\begin{tabular}{|c|c|c|c|c|c|c|c|c|}
\hline & \multicolumn{2}{|c|}{$\begin{array}{c}\text { Functional class } \\
\qquad(\text { NYHA })^{\S}\end{array}$} & \multicolumn{2}{|c|}{$\begin{array}{l}\text { Ejection fraction of } \\
\text { the left ventricle }\end{array}$} & \multicolumn{2}{|c|}{$\begin{array}{l}\text { Systemic systolic } \\
\text { blood pressure }\end{array}$} & \multicolumn{2}{|c|}{$\begin{array}{l}\text { Systemic diastolic } \\
\text { blood pressure }\end{array}$} \\
\hline & $r$ & $\mathbf{P}$ & $r$ & $\mathbf{P}$ & $r$ & $\mathbf{P}$ & $r$ & $\mathbf{P}$ \\
\hline SV & 0.06 & 0.82 & 0.05 & 0.83 & 0.170 & 0.360 & 0.15 & 0.420 \\
\hline DV & 0.28 & 0.29 & 0.10 & 0.70 & 0.367 & 0.040 & 0.44 & 0.020 \\
\hline RI & -0.41 & 0.09 & -0.14 & 0.57 & -0.470 & 0.007 & -0.56 & 0.001 \\
\hline
\end{tabular}

$\mathrm{NYHA}=$ New York Heart Association; $\mathrm{SV}=$ systolic velocity; $\mathrm{DV}=$ diastolic velocity; $\mathrm{RI}=$ resistance index

$\S=$ evaluated in heart failure patients; $r=$ Spearman correlation coefficient 
ocular perfusion, which is considered to be a risk factor for glaucoma according to current literature; moreover, this topic deserves attention and further investigation.

\section{ACKNOWLEDGEMENTS}

The authors are grateful for the financial support provided by CAPES (Coordenação de Aperfeiçoamento de Pessoal de Nível Superior) for PhD student scholarship.

\section{REFERENCES}

1. Flammer J, Orgul S. Optic nerve blood-flow abnormalities in glaucoma. Prog Retin Eye Res. 1998;17(2):267-89.

2. Flammer J, Orgul S, Costa VP, Orzalesi N, Krieglstein GK, Serra LM, et al. The impact of ocular blood flow in glaucoma. Prog Retin Eye Res. 2002;21(4):359-93.

3. Harris A, Kagemann L, Ehrlich R, Rospigliosi C, Moore D, Siesky B. Measuring and interpreting ocular blood flow and metabolism in glaucoma. Can J Ophthalmol. 2008;43(3):328-36.

4. Weinreb RN, Khaw PT. Primary open-angle glaucoma. Lancet. 2004;363(9422):1711-20. Comment in: Lancet. 2004;364(9442):1311-2.

5. Gherghel D, Orgul S, Gugleta K, Gekkieva M, Flammer J. Relationship between ocular perfusion pressure and retrobulbar blood flow in patients with glaucoma with progressive damage. Am J Ophthalmol. 2000;130(5):597-605. Comment in: Am J Ophthalmol. 2001; 1321(4):598-9.

6. Harris A, Rechtman E, Siesky B, Jonescu-Cuypers C, McCranor L, Garzozi HJ. The role of optic nerve blood flow in the pathogenesis of glaucoma. Ophthalmol Clin North Am. 2005;18(3): 345-53.

7. Michelson G, Langhans MJ, Groh MJ. Perfusion of the juxtapapillary retina and the neuroretinal rim area in primary open angle glaucoma. J Glaucoma. 1996;5(2):91-8.

8. Piltz-seymour JR, Grunwald JE, Hariprasad SM, Dupont J. Optic nerve blood flow is diminished in eyes of primary open-angle glaucoma suspects. Am J Ophthalmol. 2001;132(1):63-9.

9. Leske MC, Wu SY, Hennis A, Honkanen R, Nemesure B; BESs Study Group. Risk factors for incident open-angle glaucoma: the Barbados Eye Studies. Ophthalmology. 2008;1 15(1):85-93.

10. Choi J, Kim KH, Jeong J, Cho HS, Lee CH, Kook MS. Circadian fluctuation of mean ocular perfusion pressure is a consistent risk factor for normal-tension glaucoma. Invest Ophthalmol Vis Sci. 2007:48(1):104-11.

11. Hayreh SS, Zimmerman MB, Podhajsky P, Alward WL. Nocturnal arterial hypotension and its role in optic nerve head and ocular ischemic disorders. Am J Ophthalmol. 1994;117(5):603-24.

12. Tokunaga T, Kashiwagi K, Tsumura T, Taguchi K, Tsukahara S. Association between nocturnal blood pressure reduction and progression of visual field defect in patients with primary open-angle glaucoma or normal-tension glaucoma. Jpn J Ophthalmol. 2004; 48(4):380-5.

13. Gordon MO, Beiser JA, Brandt JD, Heuer DK, Higginbotham EJ, Johnson CA, et al. The Ocular Hypertension Treatment Study: baseline factors that predict the onset of primary openangle glaucoma. Arch Ophthalmol. 2002;120(6):714-20; discussion 829-30. Comment in: Arch Ophthalmol. 2004;122(7):1088-9; author reply 1089.

14. Drance SM, Morgan RW, Sweeney VP. Shock-induced optic neuropathy: a cause of nonprogressive glaucoma. N Engl J Med. 1973;288(8):392-5.

15. Remme WJ, Swedberg K; Task Force for de Diagnosis and Treatment of Chronic Heart Failure European Society of Cardiology. Guidelines for the diagnosis and treatment of chronic heart failure. Eur Heart J. 2001;22(17):1527-60. Erratum in: Eur Heart J. 2001;22(23):2217-8. Comment in: Eur Heart J. 2002;23(5):426; author reply 426-7.

16. Saxena PR, Schoemaker RG. Organ blood flow protection in hypertension and congestive heart failure. Am J Med. 1993:94(4A):4S-12S.

17. Almeida $O P$, Flicker $L$. The mind of a failing heart: a systematic review of the association between congestive heart failure and cognitive functioning. Intern Med J. 2001;31(5):290-5.

18. Choi BR, Kim JS, Yang YJ, Park KM, Lee CW, Kim YH, et al. Factors associated with decreased cerebral blood flow in congestive heart failure secondary to idiopathic dilated cardiomyopathy. Am J Cardiol. 2006;97(9):1365-9.

19. Gruhn N, Larsen FS, Boesgaard S, Knudsen GM, Mortensen SA, Thomsen G, et al. J. Cerebra blood flow in patients with chronic heart failure before and after heart transplantation. Stroke. 2001;32(11):2530-3.

20. Massaro AR, Dutra AP, Almeida DR, Diniz RV, Malheiros SM. Transcranial Doppler assessment of cerebral blood flow: effect of cardiac transplantation. Neurology. 2006;66(1):124-6.

21. Rajagopalan B, Raine AE, Cooper R, Ledingham JG. Changes in cerebral blood flow in patients with severe congestive cardiac failure before and after captopril treatment. Am J Med. 1984;76(5 B):86-90.

22. Roman DD, Kubo SH, Ormaza S, Francis GS, Bank AJ, Shumway SJ. Memory improvement following cardiac transplantation. J Clin Exp Neuropsychol. 1997;19(5):692-7.

23. Saha M, Muppala MR, Castaldo JE, GeeW, Reed JF $3^{\text {rd }}$, Morris DL. The impact of cardiac index on cerebral hemodynamics. Stroke. 1993;24(11):1686-90.

24. Galassi F, Sodi A, Ucci F, Renieri G, Pieri B, Baccini M. Ocular hemodynamics and glaucoma prognosis: a color Doppler imaging study. Arch Ophthalmol. 2003;121(12):1711-5.

25. Tranquart F, Berges O, Koskas P, Arsene S, Rossazza C, Pisella PJ, et al. Color Doppler imaging of orbital vessels: personal experience and literature review. J Clin Ultrasound. 2003;31(5):258-73.

26. Zelis R, Sinoway LI, Musch TI, Davis D, Just H. Regional blood flow in congestive heart failure: concept of compensatory mechanisms with short and long time constants. Am J Cardiol. 1988;62(8):2E-8E.

27. Nussbaum ES, Sebring LA, Ganz WF, Madison MT. Intra-aortic balloon counterpulsation augments cerebral blood flow in the patient with cerebral vasospasm: a xenon-enhanced computed tomography study. Neurosurgery. 1998;42(1):206-13; discussion 213-4.

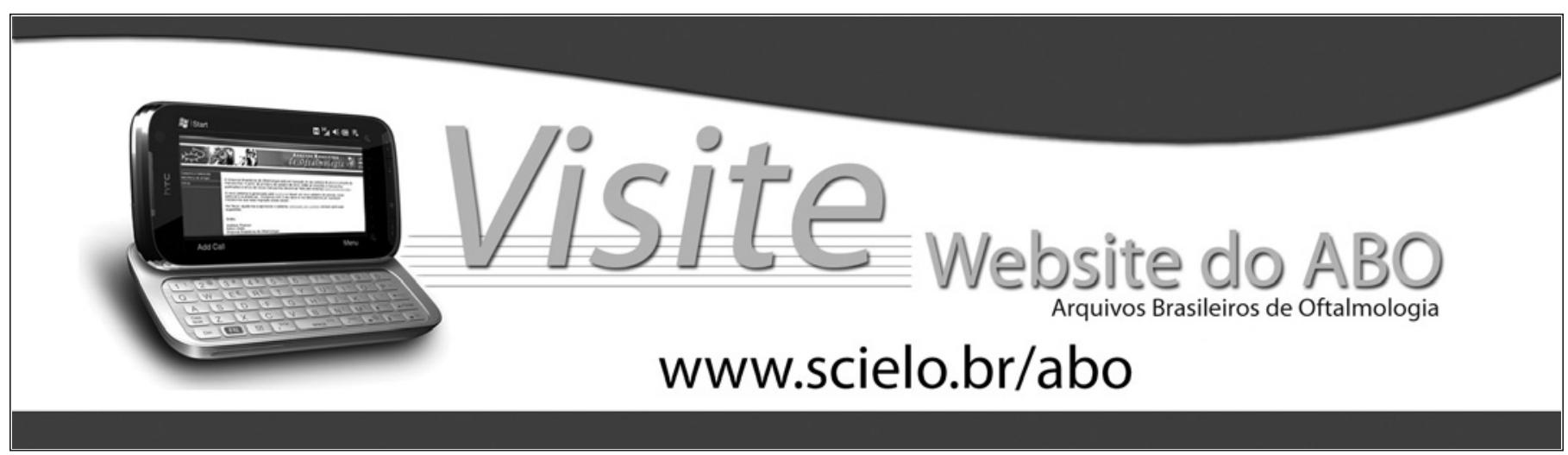

